\author{
Damian Bębnowski \\ University of Lodz \\ Faculty of Economics and Sociology \\ Department of History of Economic Thought and Economic History \\ e-mail: damian.bebenowski@uni.lodz.pl
}

\title{
The attractiveness of the project of practical methodology and virtue epistemology for the economic history research*
}

\begin{abstract}
Ewa Domańska, a distinguished historian of historiography and the methodologist of history, has provided an insightful commentary on the state of humanities and social sciences. The development of interdisciplinary research in social sciences and humanities has resulted in varying outcomes and interpenetrations. Interdisciplinary research helps the development of science. However, studies undertaken with less rigor may pose some threats into the long term. According to Domańska, the lack of qualifications and care (especially with respect to theory and methodology) may undermine the autonomy of a disciplines and the credibility of research in the given field. This timely warning prompted the author to create the project with the aim to assert the independence of the threatened disciplines and to "re-professionalize" these areas of study. This is to be achieved by emphasizing the role of theory in science - a strong embeddedness of a discipline in the theory. Domańska's concept, in the form of a dichotomous project, seems to be a recipe for achieving this goal. It presupposes, on the one hand, a "practical methodology", i.e. constructing the theory basing on empirical research material, and on the other hand the so-called "virtue epistemology", which stresses an ethical aspect of the researcher's attitude and labour.
\end{abstract}

\footnotetext{
* The article is an updated version of the paper published in Polish in the Annales. Ethics in Economic Life, 18(3), 27-44.
} 
The aim of the paper is to discuss Domańska's project and to draw attention to the originality of her concept in the context of economic and social sciences. The economic history is a peculiar discipline founded at the intersection of history and economics. Thus, it is possible to put forward the thesis that Domańska's suggestions are relevant to the research of economic history. The author will seek to determine what cognitive opportunities arise from the ontology of economic history and their potential threats to the main disciplines of history and economics. The article will also examine if Domańska's project is appropriate for the economic history research as it is deeply embedded in "practical methodology", and so in theory. Next, the author aims to consider the role of new theoretical approaches in this field, and whether it is possible to formulate novel concepts within the scope of the economic history. Finally, the author will attempt to assess the significance of "virtue epistemology" or the ethical aspect of an economic historian's work.

Keywords: theory of economic history, methodology of economic history, theory of economics, ethics of research

JEL Classification: B41, N01

\section{Introduction}

This article depicts the objectives specified in the project of practical methodology and virtue epistemology as conceived by Ewa Domańska, a Polish researcher investigating the theory and history of historiography. ${ }^{1}$ In addition, the author will attempt to apply the concept in the field of economic history and examine its utility for this discipline.

\footnotetext{
${ }^{1}$ Domańska is one of the distinguished contemporary Polish intellectuals. She graduated in history from the Adam Mickiewicz University in Poznań. In 1995, she presented her PhD dissertation in history entitled Historia $w$ czlowieku. Historiografia wobec przełomu narratywisticznego $i$ postmodernistycznego $w$ humanistyce [History in Man. Historiography in the Light of Narrative and the Postmodern Turn in the Humanities]. Jerzy Topolski was the supervisor of her thesis, while it was reviewed by Frank Ankersmit and Hans Kellner. In 2007, Domańska obtained her habilitation (postdoctoral) degree in the humanities based on her academic achievements and dissertation titled Historie niekonwencjonalne. Refleksja o przeszłości w nowej humanistyce [Unconventional Histories. Unconventional Histories. Reflections on the Past in the New Humanities], reviewed by Jacek Kochanowicz, Ryszard Nycz, Jan Pomorski and Wojciech Wrzosek. In 2016, the researcher became Professor in the humanities (full Professor) based on her academic achievements and book Historia egzystencjalna. Krytyczne stadium narratywizmu i humanistyki zaangażowanej [Existential History. Critical Approach to Narrativism and Emancipatory Humanities] (2012a). The reviewers were: Włodzimierz Bolecki, Wojciech Burszta, Krzysztof Pomian, Maria Poprzęcka and Krzysztof Zamorski. It is worth noting that due the reviews of her habilitation thesis, Domańska affiliated herself - at least on the formal, personal, and intermediate level-with economic history. Jacek Kochanowicz was an outstanding economic historian, while Jan Pomorski carried out a theoretical-methodological analysis of the "New Economic History" paradigm (Pomorski, 1995). Jerzy Topolski, the supervisor of Domańska's PhD thesis,
} 


\section{The main objectives of Domańska's project}

Domańska outlines the project of practical methodology and virtue epistemology in two articles from 2010. The then announced elaboration of her concept was published in 2012 in the last chapter of the book entitled Historia egzystencjalna [Existential History] (2012a, pp. 161-183), and she discusses it again in the text from 2014. For the purposes of our deliberations, all the above-mentioned publications are complementary - the later ones complete those that came out earlier.

By simplification, Domańska's narratives concerning the analysed project can be divided into two substantial parts. First, the researcher makes a diagnosis regarding the state of the humanities in the world (the Anglo-American part, in particular) and in Poland in the early $21^{\text {st }}$ century. Secondly, she devises a recipe for the phenomena that seem disturbing to her, specifying the objectives of the project on practical methodology and virtue epistemology.

\subsection{Diagnosis}

Domańska is extremely thorough in her analysis of the changes that occur in the contemporary humanities. Nonetheless, it should be noted that in Historia egzystencjalna, which details her concept, the scholar also extends her comments to social sciences (Domańska, 2012a, p. 164, 2014, p. 99). She claims that in the last decade, the evolutionary approach has again dominated the humanistic discourse. Furthermore, the humanities are not keeping up with the changes in the modern world. Domańska points to, among other things, technological progress, ecological crisis, natural disasters, development of global capitalism, genocide, terrorism, migrations. In her opinion, the humanities are unable to explain the

formed the group of luminaries of Polish economic historiography. Also, Krzysztof Zamorski, the reviewer of Domańska's academic achievements, specializes in socio-economic history and historical demography.

Domańska is currently affiliated with the Poznań centre and Stanford University. Her research interests revolve around such issues as: the theory and history of historiography, the methodology of history, the comparative theory of the humanities and social sciences, especially in the AngloAmerican context. She is the author of numerous respected publications, including following books: Mikrohistorie. Spotkania w międzyświatach [Microhistories: Encounters in-between-worlds] (1999), Historie niekonwencjonalne. Refleksja o przeszłości w nowej humanistyce [Unconventional Histories. Reflections on the Past in the New Humanities] (2006), History and the Contemporary Humanities: Studies in Theory of Historical Knowledge (2012b, in Ukrainian), Historia egzystencjalna. Krytyczne studium narratywizmu i humanistyki zaangażowanej [Existential History. Critical Approach to Narrativism and Emancipatory Humanities] (2012a) and Nekros. Wprowadzenie do ontologii martwego ciała [Necros: An Introduction to the Ontology of Human Dead Body and Remains] (2017).

Domańska's research constitutes an important contribution to the discussion about the impact of postmodernism on the humanities and social sciences. Moreover, the scholar from Poznan has contributed greatly to popularizing in Poland the academic output of Frank Ankersmit and Hayden White, the outstanding Western theoreticians of historiography in the field of narrativism. Domańska edited the collections of papers written by the said researchers (White, 2000, 2009, 2014; Ankersmit, 2004; Ankersmit, Domańska \& Kellner, 2009; White, 2009).

Domańska's biographical note and the outline of the bibliography of her works were developed on the basis of the information available on the researcher's website (http://ewadomanska.pl/). 
world around us in a satisfactory way, to offer constructive criticism and to come up with possible solutions. According to Domańska, this leads to the revaluation of the general concept of science. Its contemplative model that has been in use thus far loses its importance to the performative paradigm, which gives priority to usefulness, utility and effectiveness. Hence, the perennial dilemmas present themselves again, revolving around the categories of good and evil, truth, values, virtues or universals. People are looking for practical [emphasis added by the author] advice on how to live in the world where everyone has their own truth. The individuality of a person is also put into question, while the emphasis is placed on the categories of community, collective, association of humans and non-humans. More and more frequently the human is said to be merely a guest in this world, not its master. For this reason, the humanities should become performative, teaching people how to survive in the rapidly changing world (Domańska, 2010a, pp. 45-47). And so, in the contemporary humanities-concludes Domańska (2010a, p. 47):

[...] there is a marked trend promoting "critical hope" for the future, which turns away from the gothic metaphors of apocalypse, end, death and catastrophe that are typical of the postmodern thought.

The scholar, therefore, puts forward a thesis that postmodernism, along with relativism that is characteristic of it, belongs to the past. In the broadly defined culture, a new trend is crystallizing - a more optimistic one-_critical hope". 2

Domańska takes notice of a few tendencies in the contemporary humanities, which are not predominant, but they constitute, in a way, the avant-garde $(2010 \mathrm{~b}$, pp. 116-119). Among them, she mentions the coming together of the humanistic, social and exact sciences in certain research problems (2010b, pp. 116-117).

It is about [...] the change of metalanguage-Domańska explains (2010b, p. 117)-about deriving inspiration from borrowed concepts and appropriating them for the historical research, and about complementarity [emphasized by the author] - the disciplines completing one another (and not about ornamenting the humanistic studies with terms drawn from exact sciences, as physicist and biologist often complain).

Putting aside a detailed discussion on other trends, it should be underscored that Domańska recognizes the phenomenon of complementarity of approaches and research. Furthermore, in her opinion,

it might be now reasonable to lay emphasis not on the inter- and transdisciplinary approaches but on the complementary ones [...] nowadays, those are problems and not methodologies that connect disciplines. (Domańska, 2010a, p. 48)

\footnotetext{
${ }^{2}$ More on the subject of "critical hope", the trend that follows postmodernism in $O$ zmierzchu postmodernizmu (2011).
} 
In addition to complementarity, Domańska indicates the problem of incommensurability of theory and practice. In agreement with the sociologist of science Andrew Pickering, she advocates that the technological development precedes the development of science. Additionaly, there is a number of the previously mentioned phenomena resulting from rapid changes in the world. Practice is ahead of theory. The humanities cannot keep up with adapting approaches and research questions to addressed subject matters. Parallel to the incommensurability of the humanities and the surrounding reality, we can observe the incommensurability of research results and social expectations (Domańska, 2010a, pp. 48-49), which corresponds to the aforementioned matter of the performative model of science.

Citing the historians, Domańska notes that researchers see manifestations of the exhaustion and limitations of the research areas, trends and approaches that are characteristic of postmodernism. It is also associated with the said phenomenon of incommensurability of theory and practice as well as the complementarity of approaches and research (Domańska, 2010b, pp. 119-122).

Furthermore, the researcher from Poznań points out that ignoring global discussions on contemporary trends in the humanities leads to the provincialization of Polish science. The period of the People's Republic of Poland forced the necessary reception process of the West European and the Anglo-American humanistic trends in Poland as until 1989, an access to foreign literature and Western debates was limited. Yet, currently - as stated by Domańska - "Polish researchers are ready to join the process of creating the global humanistic knowledge and to become its active contributors" (2010b, p. 122). That is why they should be introducing new notions, concepts and approaches to science to render the verification and improvement of the body of knowledge. "In order to achieve this - maintains Domańska (2010b) - we need to reformulate the way we think about the role of theory and methodology in the historical research". Certainly, these remarks could be also applied to the economic history. Moreover, the author believes that we should apply the above statement also to social sciences, including economics, since Domańska extends her diagnosis to these areas as well.

Another interesting issue raised by the scholar is the autonomy and "reprofessionalization" ("re-disciplination") of the humanities and social sciences. Since Domańska's observations focus on the state of contemporary historical studies, we should relate them to economic history as well. Also, it seems reasonable to extend them to other humanistic and social sciences.

Interdisciplinary research, which has gained on popularity in recent years, favours the process of blending of different disciplines. And it is sometimes believed that if one does not go too deep into the theory and methodology (in a word, in the specificity) of specific sciences, anyone can do research on anything. Domańska does not diminish the importance of the interdisciplinary approach; on the contrary, she highlights it. Yet, she draws attention to the fact that lack of qualifications, thoroughness and knowledge about the specificity of given discipline undermines its autonomy, in addition to decreasing the level of professionalism of the research. Domańska refers to the latter consequence as "deprofes- 
sionalization". ${ }^{3}$ It is therefore indispensable - in her view- to defend the autonomy of disciplines and seek their "re-professionalization" ("re-disciplination"). It can be achieved by emphasizing the role of the theory. Moreover, once postmodernist discussions and revaluations are carried out, it is important to determine the specificity and the essence of individual disciplines anew (Domańska, 2012a, pp. 164-165, 168-169; 2014, pp. 99-100, 103-104). As for the last remark, Domańska argues that we have to reconsider the ontology and epistemology of particular sciences as part of the process, which the author of this article would call "re-conceptualization". Domańska uses the term "redefinition" in this context (Domańska, 2012a, p. 166; 2014, p. 101).

\subsection{The recipe}

And then, the question appears: what can be done? How to protect humanistic and social disciplines from the effects of the processes that Domańska points to? The recipe proposed by the scholar is a project of practical methodology and virtue epistemology, the purpose of which is to preserve the autonomy of humanistic and social sciences as well as their "re-professionalization".

In two articles from 2010, Domańska gives only a general outline of the concept of practical methodology. It has been developed later in the papers from 2012 and 2014. In Historia egzystencjalna, the scholar from Poznań clarifies the objectives of virtue epistemology.

She advances the thesis that postmodernism was characterized by the instrumental use of theory. Citing Gilles Deleuze and Michel Foucault, the researcher asserts that theory was at the time regarded as a toolbox that must be useful and functional. Hence, it was the set of ready-made analytical and interpretative instruments, which were used to produce empirical data. Although such procedures confirm the utility of the theory, if we place new problems within the framework of existing theories, approaches and concepts, the conclusions from the research become predictable. They reveal what is already known. And while it is true that conducting research within the scope of existing theories may broaden our knowledge and show a given issue in a new light, Domańska raises another problem - the instrumental, imitative and passive use of theory (Domańska, 2010b, pp. 122-123; 2010a, pp. 50-51; 2012a, pp. 170-171; 2014, pp. 104-106). She states that "those [existing thus far, in operation - author's note] theories and categories indicate what and how to see while examining a given phenomenon" (Domańska, 2010b, p. 123). On the other hand, "projecting the theory onto the material leads to $[\ldots]$ an instrumental treatment of the material" (Domańska, 2010a,

\footnotetext{
${ }^{3}$ Domańska uses the term in one of her interviews while speaking about sciences of history (Wilkowski, 2012). Ryszard Nycz refers to "undisciplination" in the context of literary studies (2010, p. 21, cited after Domańska, 2012a, p. 164).
} 
p. 51) as it is being adapted to the applied theory. ${ }^{4}$ And so, the postmodern perception of theory as a toolbox implies an instrumental use of both the theory itself and of the research material.

It should be emphasized that Domańska - at least in the analysed textsunderstands the notion of theory in rather broad terms. To her, it is a set of concepts and explanatory constructions that facilitate the conceptualization and interpretation of studied phenomena (Domańska, 2010a, p. 50; Domańska, 2010b, p. 123; Domańska, 2012a, p. 171, fn. 23; 2014, p. 106, fn. 18).

An alternative to the research that sees theory as a toolbox is the concept of practical methodology. It is used to construct theories. It is created on the basis of data analysis and it is produced specifically for data purposes. This methodology is prescriptive, but not normative; the methodology of theory, which teaches how to build a theory from the very basics; the methodology that results from a detailed analysis of the research material. It is a type of theory that advises on how to formulate concepts and derive other theories grounding in data. Practical methodology lays stress on a description and an analysis of the research material, which helps to search for concepts, generalize and consequently, to produce theory (of a short and middle range). It also teaches to elaborate a set of methodological techniques, which are to be employed while developing theory (Domańska, 2010a, pp. 49-51; Domańska, 2010b, p. 123; Domańska, 2012a, pp. 171-172; Domańska, 2014, p. 106). ${ }^{5}$ The practical methodology focuses on the methods of theory building. In this sense, it takes on the role of the methodology that puts forward a set of rules for the research procedure and with a specific purpose - to build a theory. It is the "methodology of theory building" (Domańska, 2012a, pp. 162-163).

This way, Domańska makes a distinction between practical methodology, which presupposes the theory building based on the empirical research material, and - shall we call it - theoretical methodology, which deals with abstract problems. The latter is the traditional methodology, being a branch of the methodology of sciences and, at the same time, drawing inspiration from it (Domańska, 2012a). Methodologies of specific disciplines are examples of theoretical methodology, e.g. the methodology of history (cf. Topolski, 1984) ${ }^{6}$ or methodology of economics (cf. Blaug, 1995).

\footnotetext{
${ }^{4}$ In connection with Harold Garfinkel, Krzysztof T. Konecki writes: "the theory comes first and then empirical data is adapted to it. [...] The system of arriving at theoretical conclusions may be questioned since the results of the research are only a confirmation of the previously accepted theses" (2009, pp. viii-ix, cited after Domańska, 2012a, p. 170).

5 In the context of defending the autonomy of history and its "re-professionalization", Domańska emphasizes, among other things, the significance of the empirical research material, which to a historian stands for sources: "[...] perhaps a positivistically conducted research, with its attention to detail and the peculiarities of the craft [...] while opening up to the new trends in the humanities [...] may grant it [i.e. historyauthor's note] the status of an open, dynamic framework and "a solid subject" of the humanities. [...] one should protect what is characteristic of history as a discipline, i.e. source criticism and the methodology of working with archives. Then, paradoxically, we may say that what constituted a scientific, intellectual weakness of history may actually turn out to be its strength" (2012a, pp. 168-169).

${ }^{6}$ Domańska suggests that the traditional methodology of history disregards historical research and it focuses on studying the outcomes of historians' work and cognitive activities that accompany their work (2010a, p. 50; 2010b, p. 123; 2012a, p. 172; 2014, p. 106).
} 
It turns out that in the project of practical methodology, the theory is derived from the analysis of the empirical material (Konecki, 2009, p. xii, cited after Domańska, 2012a, p. 173). The theory is thus secondary to the research material.

With respect to the concept of practical methodology, the researcher indirectly redefines the notion of the methodology itself. In her view, it is "a set of research practices, i.e. procedures and strategies that indicate how to build a theory" (Domańska, 2010a, p. 50).

Importantly, Domańska is aware of the fact that it is difficult to treat research material in a completely objective manner since any researcher always brings certain experiences, assumptions or theory to the analysis. The scholar from Poznań criticizes, however, an exclusively instrumental approach to theory and empirical material (Domańska, 2010a, pp. 51-52; 2010b, pp. 123-124; 2012a, pp. 171, $173 ; 2014$, pp. 105, 107).

Domańska does not question the significance of borrowing the theory from other disciplines. Yet, she emphasizes that nowadays we need to create new theories that would follow from the analysis of recent phenomena. What is more, the scholar suggests that existing theories should offer solely a preliminary interpretative framework and help formulate initial research questions (Domańska, 2010a, pp. 51, 54; 2010b, pp. 124, 126; 2012a, p. 171; 2014, pp. 105-106).

When new research problems - remarks Domańska (2012a, p. 171) —are put within the framework of existing cognitive theories, approaches and categories, the conclusions from such research are predictable and only confirm what we already know.

Pursuant to the rule invoked by the researcher, "new concepts and theories are needed when empiricisms (phenomena occurring in our reality), go beyond the possibilities of existing concepts and theories" (Domańska, 2010a, p. 53).

The project of practical methodology relates to the concept of grounded theory, which is to be observed, for instance, in the field of sociology (Domańska, 2010a, pp. 50-52; 2010b, pp. 124-125; 2012a, pp. 170-176; 2014, pp. 104-110). In this respect, the basic research method is a case study. It enables a new shortrange theory to crystallize through an in-depth analysis of the phenomenon, fragmentation of the problem, asking various research questions, and then creating interpretive concepts (saturated with empiricism), constructing a typology, comparing concepts, drawing conclusions and formulating hypotheses. Comparative studies constitute another important method, which makes it possible to place a specific case in a wider cognitive perspective. It is of interventional, critical and integrative character. The cosmopolitism and universality of the comparative method allow us to put together an integrated picture of an analysed phenomenon, as well as to refer to the aforementioned universals, the answers about which is sought by people of today (Domańska, 2010a, pp. 52-53; 2010b, p. 125; 2012a, pp. 173-174; 2014, pp. 107-108). 
Domańska also proposes a five-stage research procedure within the framework of practical methodology: (1) formulation of the research problem based on existing theories; (2) selection of a case, its detailed description and analysis with the application of specific research methods and interpretative strategies (case study); (3) formulation of the key concepts in the case study; (4) comparative study, taking into consideration another case; (5) presentation of the short-range theory together with definitions of the concepts as an interpretation of the results of comparisons (Domańska, 2010b, p. 126; 2012a, p. 175; 2014, pp. 108-109).

According to Domańska, by developing new theories, the project of the practical methodology can lead the humanities (and social sciences) out of the paradigmatic gap that appeared after postmodernism. ${ }^{7}$ In addition, it is an opportunity to rebuild the bridge between theory and practice; integrating and combining these two epistemological dimensions. It encourages a departure from the instrumental use of theory and research material. What is more, the practical methodology is vertical and horizontal in nature. It combines an in-depth case analysis (verticality) with extensive comparative studies (horizontality) (Domańska, 2010a, pp. 53-54; 2010b, p. 126; 2012a, pp. 166, 172, 175; 2014, pp. 101, 106, 109). Finally, as the researcher points out, the project can be helpful in the process of internationalization of the Polish and Eastern European humanities (and social sciences) and its decolonization, which is the answer to "the intellectual imperialism of Western science" (Domańska, 2012a, pp. 175-176; 2014, p. 109).

As for the protection of the autonomy and "re-professionalization" of the humanistic disciplines, Domańska believes that apart from practical methodology, "positivist atavism" also has a significant role. Applying this concept in history, the scholar understands it in terms of evolution. This atavism does not stand for regression, but for the development by means of transmitting original characteristics of the discipline - its core. It is meant to aid the self-regeneration of the discipline and ensure its survival. Domańska also emphasizes the importance of researcher's erudition and that he or she has to master specific methodologies (Domańska, 2012a, pp. 167-169; 2014, pp. 103-104).

The scholar states that the ethical dimension of research and researchers' ethical attitude are also an integral part of the practical methodology project (Domańska, 2012a, p. 176). Although Domańska specifies her view, addressing history and those researching the past, in accordance with the broad approach to the concept of practical methodology, her remarks can be applied to the humanities and social sciences also in this case. Discussing research ethics in the book Historia egzystencjalna (2012), Domańska creates the term of virtue epistemology.

\footnotetext{
${ }^{7}$ In her other works, Domańska writes about "limits of the old paradigm" (2012a, p. 166; 2014, p. 101). Cf. Domańska, 2010/2011, pp. 34-54.
} 
In this context, her reflections fit into the on-going discussions on the ethics of scientific work ${ }^{8}$ and "capitalization of the academy" (Domańska, 2012a, p. 176, fn. 35). Correspondingly, Jacek Tittenbrun writes about science being colonized by capital, as well as about the privatization and commodification of higher education (2014, pp. 169-172).

Domańska's deliberation on virtue epistemology is a nod to the issue of getting to know the universal virtues of researchers. The scholar insists that in this respect, it is crucial to study the history of virtues and values, which is represented by historians of specific schools and in specific time periods (Domańska, 2012a, pp. 176-177).

Domańska defines the notion of virtue quite broadly-as a positive moral trait and an opportunity to achieve (intellectual) goods (2012a, p. 181). And in agreement with John Greco, she explains virtue epistemology as a trend in the theory of cognition, which originates from analytic philosophy and uses the theory of virtue to solve specific problems regarding the theory of knowledge. According to the researcher, "the emphasis here is put not so much on actions as on intellectual agents and communities that are the source of epistemic values. The concept presupposes that intellectual virtues [...] condition [...] the acquisition of knowledge" (Domańska, 2012a, p. 182).

Along with the definition, Domańska's project of virtue epistemology provides the catalogue of traits that are desirable in a researcher. These include intellectual honesty (essential, according to the scholar), thoroughness, conscientiousness, intellectual courage, open-mindedness, capacity for critical thinking, moderation, responsibility, strategic naivety, ${ }^{9}$ honour, dignity, authenticity, empathy, kindness, respect, self-development, self-discipline. Furthermore, a researcher should not only teach but also educate by cultivating virtues, nurturing values and imitating masters - authority figures, being virtuous agents, play a key role in the implantation of intellectual virtues (Domańska, 2012a, pp. 177, 180-181, 183).

As mentioned earlier, Domańska aims her project of virtue epistemology at historians. Its universal character, however, makes it useful to representatives of other disciplines.

\section{Domańska's project and economic history}

In the following chapter, the author attempts to transfer Domańska's project to the field of economic history and to examine its utility for the discipline. Given that the considerations of the researcher — as it has been already mentioned — apply to

\footnotetext{
${ }^{8}$ These problems are addressed during the cyclic international scientific conference Ethics in Economic Life, held at the Faculty of Economics and Sociology of the University of Lodz.

9 By "strategic naivety" Domańska means "a pragmatic attitude, which proves that the cultivation of "naivety" is necessary to maintain the conviction about the possibility of positive changes and about the influence we have on them, as well as the possibility of both self-regenerating and rebuilding group relationships even after the times of crisis, disaster or downfall” (2012a, p. 180).
} 
the humanities and social sciences, the endeavour seems to be well-founded. Since history falls into the area of humanities, and economics belongs to social sciences, it cannot be denied that economic history-forming an integral part of both history and economics (Kula, 1983, p. 57) ${ }^{10}$-develops at the intersection of the humanities and social sciences.

To begin with, let us examine the question: what is economic history? Witold Kula (1983, p. 94) holds that is:

the study of the economic aspect of social life in various societies and cultures. It is concerned with searching for and determining regularities that occur in social economic actions (or rather in the economic aspect of social actions) as well as social factors that cause these regularities. It also deals with the economic aspect of the outcomes produced by these regularities, i.e. their intended and unintended consequences for the social economy.

Janusz Skodlarski (2005, p. 16) - in agreement with Kula-stresses that the subject of research in the case of economic history and economics is identical, while Jan Szpak (2007, p. 34) points out that "economic history studies the economic achievements of human civilization from a territorial and chronological perspective". The author is of the opinion that the scope of the definition of economic history should be as broad as possible due to its interdisciplinary character and the complexity of the issues it deals with. And so, the term of economic history is understood by the author as the study of economic reality in a given spacetime, along with all the elements and dependencies that make up this reality (Bębnowski, 2018, p. 11).

At the same time, the character of economic history allows it to open itself to other disciplines, depending on the research needs. Applying the project of practical methodology and virtue epistemology to this unique discipline seems therefore justified, cognitively inspiring and also meaningful with respect to Domańska's diagnosis of the present state of the humanities and social sciences.

Trying to define the subject of economic history, one must ask the question about the role of theory in historical economic research. But then, what is a theory in the scientific sense? Let us recall that in the view of Domańska, it is a set of explanatory notions and structures that facilitate conceptualization and interpretation of studied phenomena (2010a, p. 50; 2010b, p. 123; 2012a, p. 171, fn. 23; 2014, p. 106, fn. 18).

According to Alfred Tarski, "every scientific theory is a system of sentences which are accepted as true and which may be called laws or asserted statements or, for short, simply statements" (2012, p. 3). Furthermore, laws are accompanied by specific considerations (proofs) on the basis of which the validity of laws is assessed. The laws that are established by those proofs are referred to as theorems (2012, p. 3). To Ryszard Wójcicki, the theory is any deductive system in which

\footnotetext{
${ }^{10}$ Rafał Matera claims that economic history is one of the three main branches of economics, along with micro- and macroeconomics (2013a, p. 21;2013b, p. 9).
} 
logical and mathematical reasoning is employed. Each theory consists of three basic elements: a set of theorems, a range and language of theory (1982, pp. 104-105).

It is worth considering the reflections of Maria Lojewska, who indicates that the role of theory is to explain the known facts and empirical relationships.

Theoretical knowledge — explains the researcher (Łojewska, 1986, pp. 47-48) allows us to capture the essential features, necessary relationships, about which we draw conclusions based on the features of the objects that we perceive in the experiment, but which are in fact not given in that experiment. [...] The description of the reality at the empirical level is not an end in itself-grounding in a description of phenomena, we create theories that offer explanations. And subsequently, we refer to certain facts to verify the value of these theories. A theory is an important form of knowledge systematization - it constitutes a whole that is made of related theorems /laws of science/, which present the subject from the perspective of significant dependencies.

It is a whole by itself, but at the same time, it combines present knowledge (including empirical knowledge) into a whole. Through theory, a common ground for a variety of facts as well as relationships and dependencies between them is sought. "Creating a theory" — observes Łojewska (1986, p. 48) — "requires gaining deeper knowledge about particular facts" At the same time, the researcher explains that among the main functions of a theory are: explanation, anticipation and cognition.

Without a theory or a hypothesis — Lojewska (1986, pp. 48-49) concludes-[...] research is conducted blindly [...]. Therefore, the creation of theoretical knowledge can be defined as a criterion for the development of a given discipline, i.e. when it reaches its level of maturity. Additionally, on the basis of theory, new /empirical/ phenomena can be predicted, and new theories can be formulated. In modern science, combining different theories is [written in 1986author's note] one of the forms of knowledge integration and it is a manifestation of a relative independence of theoretical knowledge [...]. And so, grounding in developed theoretical concepts, we can create new theories and sciences.

The above comments correspond with the observations of Jerzy Wiatr, who supports the assertion that sociology is both an empirical and theoretical science. As for the latter, he writes:

Detailed data - own or taken from someone else-are of interest to it [sociology - author's note] as long as this material provides the basis for theoretical conclusions. The method of sociology understood in this way differs fundamentally from the understanding that is common in contemporary positivist sociology, which is frequently limited to collecting data (which, in many cases, ends up being a work of minor contribution) and sometimes avoids making theoretical generalizations. (Wiatr, 1962, p. 27) 
The author believes that the suggestions of the sociologist from Warsaw can also be applied to economics since it is-just like sociology-a social science. Hence, this meaning can also be attributed to theory in the context of economic history.

Summing up the observations of the above-mentioned researchers, it can be concluded that theory is a kind of skeleton or backbone of scientific research. It is an axis along which we make: conceptualizations, analysis, interpretation, synthesis, conclusions and a whole range of other activities accompanying a scientific study. What is more, in the light of Łojewska's considerations, the theory is secondary to empiricism. Abstract concepts and theoretical categories are formulated as a result of the analysis of the research material. It manifests itself especially in the methodology of grounded theory (which is popular in, for example, sociology), recalled by Domańska. Finally, theoretical knowledge gives evidence that a particular discipline is developed and mature.

What should be clearly highlighted is the fact that apart from research practice, Polish economic historians also undertake the theoretical and methodological reflection. Noteworthy considerations are the ones by Franciszek Bujak (1976), Jan Rutkowski (1947, pp. 1-26; 1982, pp. 453-592), Andrzej Grodek (1938), Witold Kula (1983), Jerzy Topolski (1964), Wojciech Morawski (2006, 2008, 2011), Julian Kuciński (1977), Janusz Skodlarski (2005, pp. 13-22; 2008a, 2008b; Marks \& Skodlarski, 1995, pp. 225-228) and Rafał Matera (2006, 2012, 2013a, 2013b).

The author will attempt to transfer Domańska's project to the field of economic history by referring to its basic postulates. First of all, within the scope of "re-conceptualization" ("redefinition", to use Domańska's term), it is necessary to constantly make repeated attempts to analyse the specificity of economic history. The author is of the opinion that those attempts should be made by providing a precise and broad definition of economic history as a discipline; determining its subject; examining issues associated with the ontology and epistemology of economic history; addressing the question of the theory and methodology of economic history; stressing its interdisciplinarity. ${ }^{11}$

It seems particularly important to emphasize the interdisciplinary nature of economic history. And, in this author's belief, there are four cognitive benefits resulting from it. Firstly, the historical perspective in the study of economic matters aids economics with empirical verification of economic theories and the possibility of formulating new theoretical approaches. Secondly, the interdisciplinary historical economic research serves the needs of history as it makes it easier to get to know the complex past reality (or at least its economic dimension). Also appealing are the materials and economic methods used in this type of research as well as the possibility of formulating rules, generalizations and regularities in the historical process. Thirdly, it is the process which inspires economic historians to

\footnotetext{
${ }^{11}$ The author makes a distinction between two types of interdisciplinarity regarding economic history: direct - encompasses history and economics, i.e. domains at the intersection of which economic history develops; indirect-is associated with disciplines to which an economic historian refers, depending on the studied matter (Bębnowski, 2018, p. 10).
} 
reach to other disciplines, e.g. political science, sociology, philosophy, anthropology. Lastly, interdisciplinary research is becoming more and more popular in the world (also in Poland). It presents a chance and, at the same time, a challenge for modern science. And it is a promising forecast for economic history (Bębnowski, 2018, pp. 12-14).

Pursuant to Domańska's recommendations, the "re-conceptualization" understood in this manner should involve referring to the strong tradition of economic historiography, while at the same time following the latest global trends in the field.

Secondly, one must not forget about "re-professionalization", i.e. maintaining a high level of historical economic research based on empirical material as well as on the theory and methodology of history and economics, and of other disciplines, depending on the subject matter. It is also connected with the necessity of devising a specific set of working techniques for an economic historian, which stems from the interdisciplinary nature of economic history. "An important aspect of a research study"-writes Domańska (2010a, p. 54)—“consists in developing your own research techniques, your own theory and methodology."

Thirdly, the defence of autonomy, according to the suggestions of the researcher, should apply to history and economics, the main disciplines at the intersection of which another science is established-economic history. Following Domańska's reasoning, these two disciplines may be threatened if the historical economic research is conducted improperly.

An increasing popularity of interdisciplinary studies (also in Poland) leads to the situation when this type of research is carried out on a massive scale. One of the consequences may be a decrease in their substantive and cognitive quality, which translates into a low level of professionalism. At this point, we can venture to distinguish two types of potential threats to history and economy resulting from the above premises. First of all, it is an ontological threat. It affects the specificity and characteristics of these disciplines. If the interdisciplinary historical economic research is not done thoroughly, and indispensable assimilation of theories and methods that are characteristic of history and economics (and possibly other fields of knowledge) does not take place, the main disciplines become "deprofessionalized". And we also run the risk of undermining their autonomy. Secondly, there is an epistemological threat. Historical economic research which is incompetent may influence negatively the learning of history and economics, leading to superficial study and a cursory use of their theoretical and methodological resources (Bębnowski, 2018, pp. 15-16).

Despite the foregoing remarks concerning the main disciplines, the author of this paper believes that economic history, which is developing since the times of Adam Smith ( $18^{\text {th }}$ century), has gained the status of a separate discipline a long time ago, and hence the need to defend its autonomy as well. It appears to be threatened with, among other things, the lack of thoroughness and knowledge in the field of historical economic research, in which reference is made to the theory and methodology of history and economics, and-indirectly - of other sciences that are attractive to an economic historian. For this reason, the education and 
technical preparation of a scholar takes on a central importance. Researchers of economic history are usually the graduates of historical or economic faculties. Accordingly, a historian should learn the essential methods of economics, and an economist - the essential methods of history. ${ }^{12}$ Conducting limited studies can pose previously described threats. One may construct an overly simplistic picture of the examined economic reality and arrive at unreliable conclusions. The economic history can be learned in a cursory manner (an epistemological threat). Or economic history may lose its attractive status of an independent discipline, melting into either history or economics - depending on the profession of a researcher (an ontological threat).

Fourthly, the role and significance of theory should be emphasized. The theory occupies a crucial role in historical economic research. And it does not seem to be an isolated view. For example, Werner Sombart writes: no theory-no history! (Sombart, 1929, p. 3). One could be tempted to say: no theory, no economic history. Skodlarski reminds us of the need to use the theory of economics in the historical economic research $(2005$, pp. 16-19; 2008a, pp. 7-10; 2008b, pp. 46-54; cf. Marks \& Skodlarski, 1995, pp. 225-228).

Thus, theory - understood as a set of concepts and categories that allow us to identify a problem and analyse it - determines the status, independence, autonomy and self-reliance of economic history. The author deems important, in this respect, both the existing theoretical concepts as well as those that are formulated on a regular basis while watching-with a critical eye - the latest trends in science. The creation of new theoretical approaches can contribute to the development of economic history. However, they should be constructed on the basis of in-depth analyses of the research material, e.g. case studies and/or comparative studies. New concepts and categories can be created only by grounding in empiricism. Translating existing theories into research material may indeed present the subject matter in a new light, but it also involves the risk of employing concepts, categories and approaches that are inadequate for the analysed phenomenon.

Fifth, the other part of Domańska's project (virtue epistemology) is equally stimulating for economic history. The author is of the opinion that Domańska's reflections on the ethical dimension of research and researcher's attitude are universal and timeless. Her list of the desirable features in a researcher should be of interest to economic historians. Additionally, the studies on the history of the virtues and values of historians, economic historians and economists should have a part in it as well. The history of historiography and the history of economic thought can also turn out to be helpful in this respect.

\footnotetext{
${ }^{12} \mathrm{Kula}$ is of the opinion that it is easier for historians to master the methods of economics than for the economists the methods of history (1983, pp. 86-87).
} 


\section{Conclusions}

How to perceive the project of practical methodology and virtue epistemology in the context of economic history? The concept of Domańska offers a recipe for the humanities and social sciences, especially for the main disciplines, i.e. those combined as part of interdisciplinary research. The project is a response to the revaluation that took place in the world of science in the era of postmodernism. As the researcher rightly observes, those changes also took place in the field of history. In her opinion, the practical methodology in connection with virtue epistemology allows history to remain an independent discipline, building its own theoreticalmethodological apparatus (Domańska, 2010b, p. 123). It seems reasonable to apply Domańska's ideas to economic history. Considering particular assumption of the analysed project in the context of historical and economic research allows us to perceive its attractiveness for the discipline that is forming at the intersection of history and economics. Therefore, the ideas of Domańska are valuable for elevating the status of economic history among historical and economic sciences as well as the humanities and social sciences. Let us conclude with the words of our protagonist: "The disciplines that grow most rapidly are the ones that invest in theoretical considerations" (Domańska, 2012a, p. 163).

\section{References}

Ankersmit, F. (2004). Narracja, reprezentacja, doświadczenie. Studia z teorii historiografii (E. Domańska, Ed.). Kraków: Universitas.

Ankersmit, F., Domańska, E., \& Kellner, H. (Eds.). (2009). Re-Figuring Hayden White. Stanford University Press.

Bębnowski, D. (2015). Atrakcyjność projektu metodologii praktycznej i epistemologii cnoty dla badań historyczno-gospodarczych. Annales. Ethics in Economic Life, $18(3), 27-44$.

Bębnowski, D. (2018). Czy istnieje przyjaźń między naukami? Polskie spojrzenie na historie gospodarcza, czyli o zwiazkach historii i ekonomii raz jeszcze [in press].

Blaug, M. (1995). Metodologia ekonomii. Warszawa: Wydawnictwo Naukowe PWN.

Bujak, F. (1976). Wybór pism (Vol. 1: Nauka, społeczeństwo, historia). Warszawa: Państwowe Wydawnictwo Naukowe.

Domańska, E. (1999). Mikrohistorie. Spotkania w międzyświatach. Poznań: Wydawnictwo Poznańskie.

Domańska, E. (2006). Historie niekonwencjonalne. Refleksja o przeszłości w nowej humanistyce. Poznań: Wydawnictwo Poznańskie.

Domańska, E. (2010/2011). Die paradigmatische Lücke (paradigmatic gap) in den heutigen Geistes- ind Sozialwissenschaften. Historie. Jahrbuch des Zentrums für Historische Forschung Berlin der Polnischen Akademie der Wissenschaften, 4, 34-54. 
Domańska, E. (2010a). Jakiej metodologii potrzebuje współczesna humanistyka? Teksty Drugie, 1-2, 45-55.

Domańska, E. (2010b). Perspektywy badań historycznych w Polsce wobec zmian we współczesnej humanistyce. In J. Kolbuszewska, \& R. Stobiecki (Eds.), Historyk wobec źródet. Historiografia klasyczna $i$ nowe propozycje metodologiczne (pp. 115-127). Łódź: Ibidem.

Domańska, E. (2012a). Historia egzystencjalna. Krytyczne studium narratywizmu $i$ humanistyki zaangażowanej. Warszawa: Wydawnictwo Naukowe PWN.

Domańska, E. (2012b). Історія та сучасна гуманітаристика: дослідження з теорї знання про минуле [History and the Contemporary Humanities: Studies in Theory of Historical Knowledge]. Київ: Ніка-Центр.

Domańska, E. (2014). W obronie dyscypliny: problem suwerenności i re-profesjonalizacji historii. In E. Domańska, R. Stobiecki, \& T. Wiślicz (Eds.), Historia - Dziś. Teoretyczne problemy wiedzy o przeszłości (pp. 99-111). Kraków: Universitas.

Domańska, E. (2017). Nekros. Wprowadzenie do ontologii martwego ciała. Warszawa: Wydawnictwo Naukowe PWN.

Grodek, A. (1938). Czego historią jest historia gospodarcza. In Pamiętnik Trzydziestolecia Szkoły Głównej Handlowej w Warszawie 1906-1936 (pp. 46-62). Warszawa: SGH.

Kuciński, J. (1977). Miejsce historii gospodarczej w systemie nauk ekonomicznych. Acta Universitatis Lodziensis. Zeszyty Naukowe Uniwersytetu Łódzkiego. Nauki Ekonomiczne i Socjologiczne, 17, 3-22.

Kula, W. (1983). Problemy $i$ metody historii gospodarczej. Warszawa: Państwowe Wydawnictwo Naukowe.

Łojewska, M. I. (1986). Filozofia nauki. Warszawa: Centralny Ośrodek Metodyczny Studiów Nauk Politycznych.

Marks, B., \& Skodlarski, J. (1995). Uwagi dotyczące nauczania historii gospodarczej na kierunkach ekonomicznych. Studia Prawno-Ekonomiczne, 52, 225-228.

Matera, R. (2006). Czy odwrót historii? Rozważania na temat miejsca historii w nauce. In J. Skodlarski (Ed.), Z historii myśli ekonomicznej i historii gospodarczej. Księga jubileuszowa prof. dr. hab. Wiesława Piątkowskiego (pp. 93-105). Łódź: Wydawnictwo Uniwersytetu Łódzkiego.

Matera, R. (2012). Interdyscyplinarny charakter historii gospodarczej. Perspektywy rozwoju dyscypliny w XXI wieku. In Z. Dziemanko \& W. Stach (Eds.), Rzeczywistość społeczna w badaniach młodych naukowców (pp. 287-306). Poznań: Wydawnictwo Maiuscula.

Matera, R. (2013a). Łączenie ekonomii i polityki w badaniach interdyscyplinarnych. Wyzwania dla ekonomisty, politologa i historyka. In M. Kalinowski \& A. Pieczewski, Polityczna kreacja ładu ekonomicznego. Teoria $i$ praktyka (pp. 17-34). Łódź: Wydawnictwo Uniwersytetu Łódzkiego.

Matera, R. (2013b). Wybrane argumenty na rzecz interdyscyplinarności badań na styku nauk ekonomicznych i politycznych. Polityka i Społeczeństwo, 4(11), 5-18.

Morawski, W. (2006). Historia gospodarcza w postmodernistycznym otoczeniu. In E. Kościk \& T. Głowiński (Eds.), Społeczeństwo i gospodarka $w$ badaniach historycznych. W 60-lecie badań statystycznych i gospodarczych na Dolnym Ślasku (pp. 13-16). Wrocław: Wydawnictwo Gajt. 
Morawski, W. (2008). Czy historia gospodarcza jest jeszcze potrzebna? In J. Skodlarski (Ed.), Historia gospodarcza $i$ historia myśli ekonomicznej a teoria ekonomii (pp. 11-17). Łódź: Wydawnictwo Uniwersytetu Łódzkiego.

Morawski, W. (2011). Czego historią jest historia gospodarcza? In R. Matera \& A. Pieczewski (Eds.), Przeglad badań nad historia gospodarcza w XXI wieku (pp. 15-25). Łódź: Wydawnictwo Uniwersytetu Łódzkiego.

O zmierzchu postmodernizmu, krytycznej nadziei i o tym, co nam zostawiła Zagłada. Z Ewą Domańską rozmawia Jacek Leociak. (2011). Zagłada Żydów. Studia $i$ Materiaty, 7, 507-517.

Pomorski, J. (1995). Paradygmat "New Economic History”. Studium z teorii rozwoju nauki historycznej. Lublin: Wydawnictwo Uniwersytetu Marii Curie-Skłodowskiej.

Rutkowski, J. (1947). Historia gospodarcza Polski (Vol. 1: Czasy przedrozbiorowe). Poznań: Księgarnia Akademicka.

Rutkowski, J. (1982). Wokót teorii ustroju feudalnego. Prace historyczne. Warszawa: PIW.

Skodlarski, J. (2005). Zarys historii gospodarczej Polski. Warszawa: Wydawnictwo Naukowe PWN.

Skodlarski, J. (2008a). O potrzebie rozważań metodologicznych. In J. Skodlarski (Ed.), Historia gospodarcza i historia myśli ekonomicznej a teoria ekonomii (pp. 7-10). Łódź: Wydawnictwo Uniwersytetu Łódzkiego.

Skodlarski, J. (2008b). Związki historii gospodarczej z teorią ekonomii. In J. Skodlarski (Ed.), Historia gospodarcza $i$ historia myśli ekonomicznej a teoria ekonomii (pp. 46-54). Łódź: Wydawnictwo Uniwersytetu Łódzkiego.

Sombart, W. (1929). Economic theory and economic history. Economic History Review, 2(1), 1-19.

Stobiecki, R. (2014). Historycy polscy wobec wyzwań XX wieku. Poznań: Wydawnictwo Nauka i Innowacje.

Szpak, J. (2007). Historia gospodarcza powszechna. Warszawa: Polskie Wydawnictwo Ekonomiczne.

Tarski, A. (2012). Wprowadzenie do logiki i do metodologii nauk dedukcyjnych. Warszawa: Philomath.

Tittenbrun, J. (2014). Kolonizacja nauki i świata przez kapitat. Teoria światów równoległych $w$ wydaniu socjologii wiedzy. Poznań: Zysk i S-ka.

Topolski, J. (1964). Historia gospodarcza a teoria ekonomii. Kwartalnik Historyczny, 71(1), 79-90.

Topolski, J. (1984). Metodologia historii. Warszawa: Państwowe Wydawnictwo Naukowe.

White, H. (2000). Poetyka pisarstwa historycznego (E. Domańska \& M. Wilczyński, Eds.). Kraków: Universitas.

White, H. (2009). Proza historyczna (E. Domańska, Ed.). Kraków: Universitas.

White, H. (2014). Przeszlość praktyczna (E. Domańska, Ed.). Kraków: Universitas.

Wiatr, J. J. (1962). Szkice o materializmie historycznym i socjologii. Warszawa: Książka i Wiedza. 
Wilkowski, M. (2012). Ewa Domańska o projekcie historii egzystencjalnej. http:// historiaimedia.org/2012/06/25/ewa-domanska-o-projekcie-historii-egzystencjalnej/

Wójcicki, R. (1982). Wyktady z metodologii nauk. Warszawa: Państwowe Wydawnictwo Naukowe.

http://ewadomanska.pl/ 